Henning Bergenholtz \& Finn Frandsen*

\title{
Hermes - tidsskrift for sprogforskning 1988-1998
}

Set under evighedens synsvinkel kan det næppe siges at være nogen stor historisk begivenhed, at et fagtidsskrift som Hermes - tidsskrift for sprogforskning kan fejre sit ti års-jubilæum. Det er jo overgået så mange andre tidsskrifter i tidens $1 \varnothing b$ - store som små, nationale som internationale; selv om man naturligvis ikke skal glemme det store kontingent af periodica, der kun lever nogle ganske få år eller sågar måneder. Når vi alligevel føler trang til at markere jubilæet, så skyldes det ikke kun, at forfatterne til denne lille indledning i al ubeskedenhed selv har været med til grundlægge Hermes, men også, at projektet syntes at være næsten dødsdømt fra begyndelsen.

Året 1987 var ikke det mindst vigtige år i Det erhvervssproglige Fakultets historie. Først og fremmest var der for alvor kommet gang i nyansættelserne, fra kandidatstipendiater og adjunkter til lektorer og "superprofessorer". Dette betød for det første, at der kom langt mere gang i fakultetets forskning - og ikke mindst i offentliggørelsen af resultaterne af denne forskning, og for det andet, at der blevet taget nye forskningsrelaterede initiativer. To af disse initiativer var oprettelsen af henholdsvis Lingvistisk Kollokvium og Hermes - tidsskriftet for sprogforskning. Med fakultetets forskningsudvalg som organisatorisk ramme og primus motor blev der således fra foråret 1988 afholdt foredrag i Lingvistisk Kollokvium. Disse foredrag blev nogle få måneder senere offentliggjort i et tidsskrift, som fik navnet Hermes - opkaldt efter den græske gud for det, man med et moderne udtryk ville kalde for "kommunikation og handel". Siden da har man forrest i hvert nummer af tidsskriftet kunnet finde følgende ordveksling fra Platons dialog Kratylos:

* Henning Bergenholtz \& Finn Frandsen

Handelshфjskolen $i$ Århus

Fuglesangs Allé 4

DK-8210 Arhus $V$ 
Hermogenes:

Bare en ting vil jeg gerne spørge dig om endnu: hvad betyder "Hermes" egentlig?

Sokrates:

Dette navn har ihvertfald noget med ord og tale at gøre. For Hermes er tolk, sendebud, en snedig tyv og bedragerisk med sine ord og desuden en dygtig handelsmand, og alt dette beror jo på talens magt.

Lad os med det samme afsløre, at det langt fra var alle, som troede på vores idé. Mange var naturligvis positivt indstillet over for tanken om, at fakultetet skulle udgive et lingvistisk fagtidsskrift, men mindst lige så mange mente, at det nok trods alt var et urealistisk projekt. Det gjaldt for eksempel vores daværende dekan, professor Sven-Olaf Poulsen, der på sin sædvanlige venlige måde fortalte undertegnede, at redaktionen formodentlig ikke kun ville blive nødt til at udddele numrene gratis - for hvem i Danmark ville dog betale penge for at læse artikler om sprogvidenskabelige emner udgivet af Det erhvervssproglige Fakultet ved Handelshøjskolen i Århus? - men at de også ville være tvunget til selv at skulle skrive disse artikler!

Helt så galt gik det nu ikke. Hermes nr. 1, der omfattede over 250 sider, udkom i september måned 1988 i et oplag på 300 eksemplarer, som blev sendt eller uddelt gratis til interesserede læsere. Allerede fra og med Hermes nr. 2 skulle man dog betale for at abonnere. Som det fremgår af den redaktionelle leder $\mathrm{i}$ det første nummer, skulle tidsskriftet tjene et dobbelt formål:

"For det første skal det være et forum for den erhvervssproglige hhv. fagsproglige forskning på handselshøjskolerne i Danmark. Dette endnu ret nye område oplever i disse år et opsving på både nationalt og internationalt niveau, hvad der gør udgivelsen af et tidsskrift endnu mere påkrævet. Men tidsskriftet skal for det andet også være et formidlingssted for moderne sprogforskning i almindelighed. Tidsskriftets målgruppe er således ikke kun forskere på handelshøjskolerne, men i princippet alle, som beskæftiger sig med sprog og sprogvidenskab i Danmark og resten af Skandinavien."

Og artiklerne i det første nummer afspejlede udmærket dette dobbelte formål: der var artikler om så vidt forskellige emner som lingvistiske forskningsmetoder, konjunktiv på tysk og modalverber på en- 
gelsk, radiærordbøger, passiv og tomme NP'er, semantiske neologismer og semantisk isotopi samt tekstlingvistik og tekstanalyse.

Ud over sektionen med de egentlige videnskabelige artikler indeholdt Hermes også andre faste rubrikker. Det var var f.eks. en rubrik med overskriften "Synspunkt", hvor forskere eller forskningsadministratorer kunne formulere deres mere eller mindre kontroversielle holdninger til videnskab i almindelighed og sprogvidenskab i særledeshed. Bl.a. tidligere undervisningsminister Bertel Haarder har udtrykt sig her:

"Hermes var ikke blot gudernes sendebud og handelens beskytter. Oprindelig var han i Arkadien frugtbarhedens gud. Det var logisk, at han senere blev sat $\mathrm{i}$ forbindelse med gevinsten, det være sig den ærlige (handel) eller den uærlige (tyveri)" (Hermes nr. 2, 1989).

“Synspunkt" eksisterer desværre ikke længere. Det gør til gengæld to andre rubrikker, "Forum" og "Anmeldelser", hvor sigtet med den første var at give forskerne mulighed for at præsentere og diskutere nye projekter, forskningsresultater eller korpora på en mere bred måde, mens den anden rubrik naturligvis var helliget anmeldelser af den nyeste faglitteratur. Anmeldelsessektionen er i øvrigt vokset og vokset i de senere år, således at Hermes i dag formodentlig er et af de tidsskrifter i Norden, hvor der mest intensivt og mest vidtfavnende anmeldes lingvistisk faglitteratur. Vi henviser i denne forbindelse til vores fælles artikel "At anmelde i Hermes - tidsskrift for sprogforskning” i Hermes nr. 19 (1997).

Siden 1988 har der naturligvis været forskellige omslag i tidsskriftets historie. Det gælder såvel redaktører som redaktionssekretærer. Den første redaktion bestod af Henning Bergenholtz og Finn Frandsen, der sammen med Sven-Olaf Poulsen, Bent Jacobsen, Kjær Jensen og Helmut Molly tillige udgjorde den første redaktionskomité. Fra 1990 til 1992 (nr. 5-8) bestod redaktionen af Henning Bergenholtz og Helmut Molly, fra 1992 til 1998 (nr. 9-21) af Finn Frandsen alene, og fra og med Hermes nr. 22 vil redaktionen bestå af Henning Bergenholtz og Jan Engberg. Hvad angår sekretærhjælp, var Richard Almind tidsskriftets første layouter og redaktionssekretær. Disse opgaver blev fra og med nr. 9 (1992) overtaget af Marie-France Pors (sats) og Elin Madsen (redaktionssekretær).

Der har også været forskellige omslag i den redaktionelle linje. Det første vigtige skift fandt sted med udgivelsen af Hermes nr. 6 (1991), hvor redaktionen besluttede at gøre Hermes til et internationalt tids- 
skrift med bidrag på engelsk, tysk eller fransk. Som redaktionen selv udtrykte det på dette tidspunkt:

"It was also the intention of the journal to contribute to international scientific discussion, and Danish represents the language of only a relatively small population. This dilemma, which confronts all minor languages, necessitates a choice: either one keeps Danish as the language of publication, with all the limitations this involves, or one publishes more articles in major languages."

Internationaliseringen af tidsskriftet var dog på sin vis allerede gået i gang, i og med at flere og flere artikler i de første fem numre af Hermes var forfattet på et andet sprog end dansk. Et fuldstændigt farvel til dansk som forskningssprog blev der heller ikke tale om. Hermes forblev - og er stadig et "omnibustidsskrift", der særligt retter sig mod danske læsere (og først i anden omgang mod andre skandinaviske eller europæiske læsere). Nogle af bidragene, særligt de artikler, der behandler kontrastive aspekter, offentliggøres således ofte på dansk.

At internationalt anerkendte forskere fra det store udland har bidraget til Hermes, kan måske ikke ligefrem kaldes for et "omslag i den redaktionelle linje", men vi er meget stolte over at have offentliggjort artikler, skrevet specialt til Hermes, af så kendte sprogforskere som f.eks. Deirdre Wilson, François Rastier, Katharina Reiss, Rob Grootendorst, Burkhard Schaeder, Georges Kleiber, Daniel Gile, Vijay Bhatia, Jacques Moeschler eller Herbert Ernst Wiegand. Tidsskriftets redaktører har dog altid fastholdt ideen om, at Hermes først og fremmest skulle være et sted, hvor fakultetets egne forskere kunne komme til orde.

Det andet vigtige redaktionelle skift fandt sted med udgivelsen af Hermes nr. 11 (1993), der var det første temanummer i tidsskriftets historie. Det handlede om interkulturel kommunikation, men siden da har der været udgivet temanumre om oversættelse, korpuslingvistik, tolkeforskning, forhandlingssprog, tekstlingvistik, grammatologi, fagleksikografi og teksttyper.

Igennem årenes løb har der dog ikke kun været udskiftninger og omslag. Der har i høj grad også været udvidelser. Det gælder ikke alene antallet af faste abonnenter, som i dag er på over 200, og hvoraf en betragtelig del er udenlandske. Det gælder heller ikke kun antallet af sider i hvert nummer - det tyndeste har været på 137 sider og det tykkeste på 
ikke mindre end 376 sider - eller antallet af anmeldelser. Hermes har nemlig også "formeret" sig i den forstand, at tidsskriftet fra og med 1997 etablerede en skriftserie, hvori der foreløbig er udkommet to bind, nemlig C. Hansen (red.): Anmeldelsens teori og praksis (1997) og H. Pors, L. Falster Jakobsen \& F. Talbo Stubkjær (red.): Sprachgermanistisk in Skandinavien III (1997).

Det første nummer af Hermes, som udkom i september 1988, bestod næsten udelukkende af artikler, der var skrevet af forskere fra Det erhvervssproglige Fakultet ved Handelshøjskolen i Århus, og som byggede på foredrag, der var blevet holdt i Lingvistisk Kollokvium. I dag, ti år og tyve numre senere, har vi valgt at følge samme fremgangsmåde. Med nogle få undtagelser er artiklerne i dette nummer således blevet holdt som foredrag i Lingvistisk Kollokvium i foråret 1998. På denne måde kan vi ikke alene fejre det dobbelte ti års-jubilæum; man kan også danne sig et indtryk af, hvordan den erhvervssproglige forskning på fakultetet i dag tager sig ud.

Og havde vi ikke selv kunnet udfylde nummeret, ville vi have kunnet bringe nogle af de mange andre artikler, der uopfordret bliver os tilsendt fra såvel danske som udenlandske sprogforskere, og som er det bedste bevis på, at Hermes i dag er et etableret fagstidsskrift, som lever i bedste velgående. Det er ikke længere nødvendigt, og det har heller aldrig rigtig været det, at redaktørerne uddeler Hermes gratis, endsige selv skriver alle bidragene. Og det er naturligvis vores håb, at det også vil forblive sådan de næste ti år. 
